Museum breaks mould in attempts to
lure reluctant visitors

Jim Giles, London

Museum curators are fond of saying that people visit their exhibits only three times: as children, with their own children, and again with their grandchildren. Now Britain's Science Museum is confronting this sorry situation head-on, opening a $\mathfrak{E} 10$-million (US\$17-million) centre aimed directly at adults.

The Dana Centre in South

Kensington, London, will open its doors on 19 November and is targeted squarely at visitors aged 18-45. Events will range from evening discussions on AIDS in ethnic minority communities, to film premières, as well as giving visitors the chance to watch a live broadcast of a heart operation and quiz the surgeons involved.

The centre could also feature risqué happenings more associated with other adults-only venues. Dana Centre staff point out that the museum's stores contain Victorian sex toys, and the centre's child-free environment might make it possible to run events themed on such objects.

"It they pull this off it will be incredible," says Steve Cross, sciencedevelopment manager at the Life Science Centre in Newcastle upon Tyne, UK. Adults aged 18-45 tend to have established interests, he points out, and it is tough to make them take a second look at science. "Everyone in the sciencecommunication world is scared of that age range," says Cross. "If they succeed they will have rewritten the rules."

The centre may also struggle to achieve its aim of attracting visitors in the evening, sceptics say. South Kensington is certainly better known for its museums and embassies than for its nightlife.

But the centre's staff counter that such problems can be overcome by hosting carefully designed events. This February, for example, the museum successfully targeted the Afro-Caribbean community with a lecture timed to coincide with Motherland, a BBC television documentary in which DNA analysis was used to help British Afro-Caribbeans trace their ancestry back to specific parts of Africa.

As well as hosting science events based on stand-up comedy and contemporary dance, the centre hopes to build on the success of the Café Scientifique idea of holding events in bars and cafés at which visiting researchers discuss scientific topics. Such events already take place across Europe and the United States. www.danacentre.org.uk

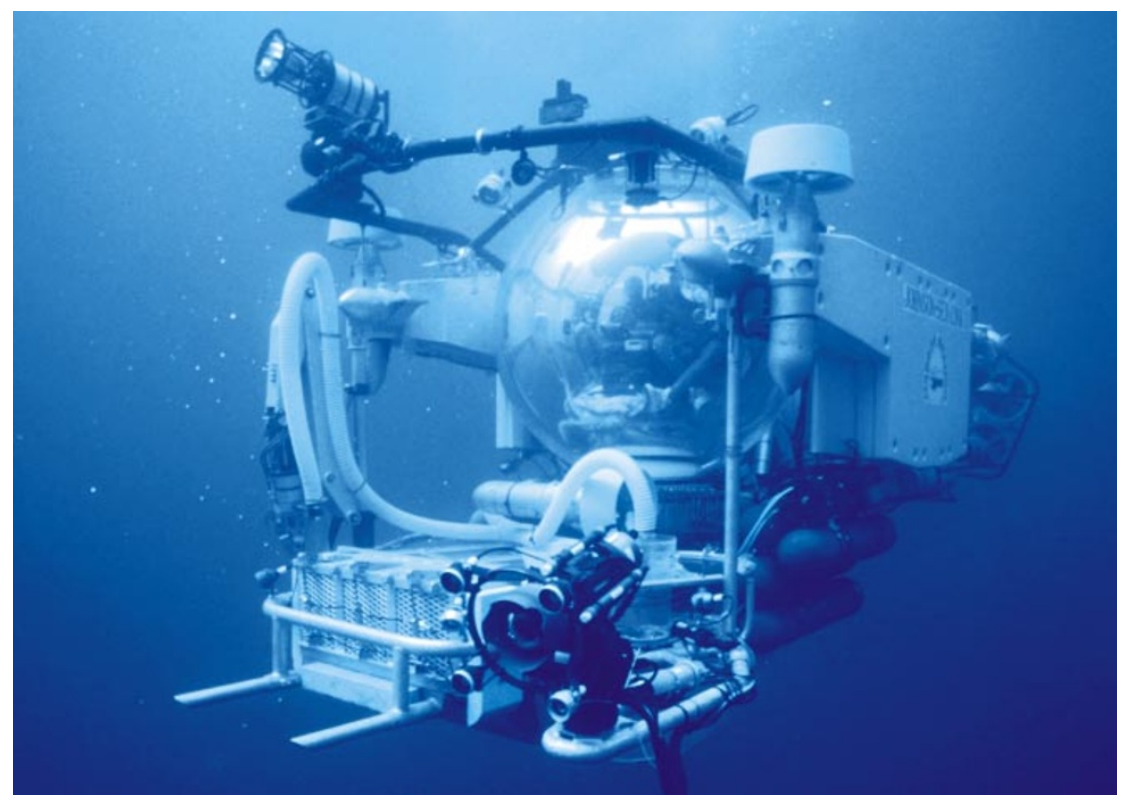

Hidden depths: research missions are ignoring previously unexplored areas of the oceans.

\title{
National Academy calls for sea change in ocean efforts
}

\section{Betsy Mason, Washington}

The United States isn't doing enough to explore the oceans, and needs to develop an inter-agency approach to such exploration, says a committee of the National Academy of Sciences.

An academy panel says that a better understanding of the oceans requires a major, coordinated, international effort to investigate unexplored regions. And the best way to get such an effort under way is for the United States to take the lead, in the hope that other countries will follow suit, the panel concludes in a report released on 4 November.

Since 2000, the US government has sponsored a small ocean-exploration programme at the National Oceanic and Atmospheric Administration (NOAA), but limited funding has kept most projects from venturing beyond North American coastal waters.

Outside NOAA, most ocean research has focused on specific objectives that often involve further study of already known areas. Little money or effort has gone into pure exploration, and most discoveries occur serendipitously, says the panel.

"We need to encourage and nurture that type of serendipity," says biological oceanographer and panel member Shirley Pomponi of Harbor Branch Oceanographic Institution in Fort Pierce, Florida.

The only way to achieve this is to make funds available specifically for exploring new areas such as the Southern and Arctic oceans, says committee chair John Orcutt, a marine geophysicist at Scripps Institution of
Oceanography in La Jolla, California. The panel estimates that a high-quality programme, including a fleet of submersibles and research vessels, would need around $\$ 270$ million to set up and $\$ 110$ million in annual operating costs. A more modest programme that could still achieve many of the exploration goals would cost $\$ 70$ million per year. NOAA gets just $\$ 14$ million a year for its existing programme.

The panel is critical of NOAA's ability to handle a larger programme, however, and says that an inter-agency approach would be a better solution.

But James Baker, president of the Academy of Natural Sciences in Philadelphia and former NOAA head under the Clinton administration, thinks that the programme would do better inside NOAA or another existing agency. "Big initiatives always do best if they are single-agency efforts," says Baker. "We need to pick one and make it work."

Congressman Jim Greenwood (Republican, Pennsylvania), a member of the House Oceans Caucus who was instrumental in asking for the report, strongly endorsed its findings. "By not exploring the rest of the oceans, we are missing the opportunity to discover all kinds of pharmaceuticals and natural resources," he says.

Greenwood says he is optimistic that the Bush administration will look seriously at supporting ocean research, to boost its environmental reputation. "A robust and romantic approach to exploring the oceans would be good policy and good politics," he says. 